\title{
Novel 24-membered macrolides, JBIR-19 and -20 isolated from Metarhizium sp. fE61
}

\author{
Ikuko Kozone $^{1}$, Jun-ya Ueda ${ }^{1}$, Machika Watanabe ${ }^{2}$, Satoru Nogami ${ }^{2}$, Aya Nagai ${ }^{1}$, Shigeki Inaba ${ }^{3}$, \\ Yoshikazu Ohya ${ }^{2}$, Motoki Takagi ${ }^{1}$ and Kazuo Shin-ya ${ }^{4}$
}

In the course of our screening program for active compounds that induce cell morphological changes of Saccharomyces cerevisiae, the culture broth of an entomopathogenic fungus Metarhizium sp. fE61 exhibited a unique morphological phenotype. We conducted an activity-guided isolation from the fermentation broth of Metarhizium sp. fE61 to yield two new macrolide compounds named JBIR-19 (1) and -20 (2) as active substances. Their structures were determined to be 24-membered macrolide analogs containing a 2-aminoethyl phosphate ester on the basis of NMR and other spectroscopic data. Compounds 1 and 2 induced striking elongated morphology of $S$. cerevisiae at concentrations of 3.1 and $13 \mu \mathrm{m}$, but showed weak antiyeast activity at MICs of 200 and $>200 \mu \mathrm{M}$, respectively.

The Journal of Antibiotics (2009) 62, 159-162; doi:10.1038/ja.2009.5; published online 6 February 2009

Keywords: cell morphology; JBIR-19; JBIR-20; 24-membered macrolide; Metarhizium sp.; Saccharomyces cerevisiae

\section{INTRODUCTION}

Cell morphology is tightly linked to cellular processes and functions in virtually all eukaryotic organisms. In the budding yeast Saccharomyces cerevisiae, cell morphology reflects various cellular events, including progression through the cell cycle, establishment of cell polarity and regulation of cell-size control. ${ }^{1}$ Change of the cell morphology often occurs as a consequence of cellular differentiation, cellular toxicity, other critical cellular events or signaling. Therefore, we can estimate the target of compounds from the information of yeast morphological changes induced by the compounds. In addition, the observation of morphological changes that provides a different viewpoint from antifungal activity-based screening could be one of the screening methods to discover bioactive compounds with novel skeletons, although these compounds do not show direct cytocidal activity in yeast. Accordingly, we carried out the chemical screening focusing on a specific morphology of $S$. cerevisiae.

We observed visually the cell morphology of diploid wild-type S. cerevisiae treated with microbial metabolites by phase contrast microscopy, and screened for inducers of abnormal morphological phenotypes. In the results, we found active ingredients in the fermentation broth of an entomopathogenic fungus identified as Metarhizium sp. We carried out activity-guided separation from the culture broth to isolate two new 24-membered macrolide compounds designated as JBIR-19 (1) and -20 (2). This study describes the fermentation, isolation, structure elucidation and biological activity of 1 and 2, in addition to the taxonomy of the producing microorganism.

\section{MATERIALS AND METHODS}

General experimental procedures

The melting point was determined with a Yanagimoto micro melting point apparatus (Kyoto, Japan). Optical rotations were operated on a Horiba SEPA300 polarimeter (Kyoto, Japan). HR-ESI (electrospray ionization)-MS data were recorded on a Waters LCT-Premier XE mass spectrometer (Milford, MA, USA). UV and IR spectra were measured on an Hitachi U-3200 spectrophotometer (Tokyo, Japan) and an Horiba FT-720 spectrophotometer (Kyoto, Japan), respectively. The ${ }^{1} \mathrm{H}$ and ${ }^{13} \mathrm{C}$ NMR spectra were taken on a Varian NMR System 500 NB CL (Palo Alto, CA, USA) in DMSO- $d_{6}$, with the residual solvent peak as internal standard $\left(\delta_{\mathrm{C}} 39.7, \delta_{\mathrm{H}} 2.49\right.$ p.p.m.). The ${ }^{31} \mathrm{P}$ NMR spectra were taken on a Varian NMR System 400 MR in DMSO- $d_{6}$ with phosphoric acid as internal standard $\left(\delta_{\mathrm{p}} 0\right.$ p.p.m.). Analytical TLC was carried out on precoated silica gel $60 \mathrm{~F}_{254}$ plates $(0.25 \mathrm{~mm}$ thickness; Merck, Darmstadt, Germany), and a phosphomolybdic acid solution was used for the detection. Normal- and reversed-phase medium pressure liquid chromatography was performed on a Purif-Pack SI-60 and a Purif-Pack ODS-100 (Moritex, Tokyo, Japan), respectively. Preparative reversed phase HPLC was carried out on a Senshu Pak PEGASIL ODS (20 i.d. $\times 150 \mathrm{~mm}$; Senshu Scientific, Tokyo,

\footnotetext{
${ }^{1}$ Biomedicinal Information Research Center (BIRC), Japan Biological Informatics Consortium (JBIC), Koto-ku, Tokyo, Japan; ${ }^{2}$ Department of Integrated Biosciences, Graduate School of Frontier Sciences, University of Tokyo, Kashiwa, Chiba, Japan; ${ }^{3}$ NITE Biotechnology Development Center (NBDC), Department of Biotechnology, National Institute of Technology and Evaluation (NITE), Kisarazu, Chiba, Japan and "Biomedicinal Information Research Center (BIRC), National Institute of Advanced Industrial Science and Technology (AIST), Koto-ku, Tokyo, Japan

Correspondence: Dr K Shin-ya, Biomedicinal Information Research Center (BIRC), National Institute of Advanced Industrial Science and Technology (AIST), 2-42 Aomi, Koto-ku, Tokyo 135-0064, Japan. E-mail: k-shinya@aist.go.jp or Dr M Takagi, Biomedicinal Information Research Center (BIRC), Japan Biological Informatics Consortium (JBIC), 2-42 Aomi, Koto-ku, Tokyo 135-0064, Japan.

E-mail: motoki-takagi@aist.go.jp

Received 8 December 2008; revised 13 January 2009; accepted 19 January 2009; published online 6 February 2009
} 
Japan) with detection by a Waters 2996 photodiode array detector and a Waters 3100 mass detector. Reagents and solvents were of the highest grade available.

\section{Microorganism}

The producing organism, designated as fE61, was isolated by the SDS-YE method $^{2}$ from a soil sample collected in Kyoto Prefecture, Japan. The soil was treated with a solution containing 6\% Bacto-Yeast Extract (BD Biosciences, San Jose, CA, USA) and $0.05 \%$ sodium dodecyl sulfate at $40^{\circ} \mathrm{C}$ for $20 \mathrm{~min}$. The solution was diluted with water and plated onto potato dextrose agar plates at $27^{\circ} \mathrm{C}$ for a few weeks. The fungal colonies that appeared on the plate were transferred to potato dextrose agar slant and the strains were maintained.

The fE61 strain was identified through sequence analysis of the ribosomal DNA ITS region and the microscopic feature was observed by using a Zeiss Axio Plan 2 imaging system (Carl Zeiss, Oberkochen, Germany).

Wild-type diploid Saccharomyces cerevisiae strain (BY4743: MATa/MATa;

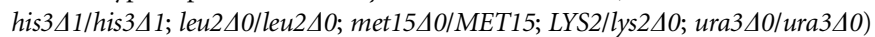
was obtained from the European Saccharomyces cerevisiae Archive for Functional Analysis (EUROSCARF). ${ }^{3}$

\section{Medium}

The seed medium, potato dextrose, was composed of $2.4 \mathrm{gl}^{-1}$ Potato dextrose broth (BD Biosciences). The production medium consisted of $15 \mathrm{~g}$ oatmeal (Quaker, Chicago, IL, USA) and $50 \mathrm{ml}$ V8 Mix Juice (Campbell Soup Company, Camden, NJ, USA) in 500-ml Erlenmeyer flasks.

Yeast cells were grown in a Yeast-Peptone-Dextrose (YPD) medium containing 1\% Bacto-Yeast Extract (BD Biosciences), 2\% Bacto-Peptone (BD Biosciences) and $2 \%$ dextrose.

\section{Cell morphology assay}

For morphological screening, diploid wild-type S. cerevisiae was grown in 96-well microtiter plates with YPD liquid media. The culture of logarithmically growing wild-type cells was diluted to $2 \times 10^{4}$ cells per $\mathrm{ml}$, dispensed $100 \mu \mathrm{l}$ to each well in 96-well microtiter plates and incubated in the presence of $5 \%$ screening sample at $25^{\circ} \mathrm{C}$ with constant shaking. After a day's incubation, the cells were observed by phase contrast microscopy (AXIO Imager M1, Carl Zeiss).

\section{Antibiotic assay}

The MIC determinations of $\mathbf{1}$ and $\mathbf{2}$ were conducted in 96-well microtiter plates with YPD liquid media. The culture of logarithmically growing wild-type S. cerevisiae cells was diluted to $2 \times 10^{4}$ cells per $\mathrm{ml}$ and incubated in the presence of different concentrations of compounds at $25^{\circ} \mathrm{C}$ with constant shaking. MIC was determined as the lowest concentration of drugs at which no significant visible growth occurred after a day. The cell number was observed by phase contrast microscopy (AXIO Imager M1, Carl Zeiss).

\section{RESULTS AND DISCUSSION}

\section{Taxonomy and fermentation}

The producing microorganism showed $99.2 \%$ similarity to Metarhizium anisopliae var. anisopliae (EU307926) using sequence analysis of ribosomal DNA and morphological features such as profusely branched conidiophores forming a sporulating layer and dry subhyaline phialoconidia compacted into regular chains and columns. ${ }^{4,5}$ Hence, the strain was identified as Metarhizium sp.

Metarhizium sp. fE61 was cultivated in a 50-ml test tubes containing $15 \mathrm{ml}$ of a seed medium. The test tubes were shaken on a reciprocal shaker ( 355 r.p.m.) at $27^{\circ} \mathrm{C}$ for 3 days. Aliquots $(5 \mathrm{ml})$ of the culture were transferred to $500-\mathrm{ml}$ Erlenmeyer flasks containing the production medium and incubated in static culture at $27^{\circ} \mathrm{C}$ for 14 days.

\section{Isolation}

The solid culture (eight flasks) was extracted with $80 \%$ aq. $\mathrm{Me}_{2} \mathrm{CO}$. After concentration in vacuo, the aqueous concentrate was partitioned with EtOAc $(1000 \mathrm{ml})$ and $n-\mathrm{BuOH}(1500 \mathrm{ml})$, successively. The
Table 1 Physicochemical properties of 1 and 2

\begin{tabular}{|c|c|c|}
\hline & 1 & 2 \\
\hline Appearance & $\begin{array}{l}\text { Colorless amorphous } \\
\text { powder }\end{array}$ & $\begin{array}{l}\text { colorless amorphous } \\
\text { powder }\end{array}$ \\
\hline Melting point & $160-162^{\circ} \mathrm{C}$ & $126-128^{\circ} \mathrm{C}$ \\
\hline$[\alpha]_{D}^{25}(\mathrm{MeOH})$ & $+31.9(c 0.7)$ & $+25.9(c 0.3)$ \\
\hline $\begin{array}{l}\text { HR-ESI-MS }(m / z) \text { found } \\
\text { calculated }\end{array}$ & $\begin{array}{l}550.3142(\mathrm{M}+\mathrm{H})^{+} \\
550.3145 \\
\left(\text { for } \mathrm{C}_{26} \mathrm{H}_{49} \mathrm{NO}_{9} \mathrm{P}\right)\end{array}$ & $\begin{array}{l}534.3166(\mathrm{M}+\mathrm{H})^{+} \\
534.3196 \\
\left(\text { for } \mathrm{C}_{26} \mathrm{H}_{49} \mathrm{NO}_{8} \mathrm{P}\right)\end{array}$ \\
\hline UV $\lambda_{\max }(\mathrm{MeOH}) \mathrm{nm}(\varepsilon)$ & 204 (1093) & 204 (1007) \\
\hline IR $v_{\max }(\mathrm{KBr}) \mathrm{cm}^{-1}$ & $3400,1730,1630$ & $3400,1726,1631$ \\
\hline
\end{tabular}

$\mathrm{BuOH}$ layer was evaporated to dryness in vacuo, and the dried residue $(1.9 \mathrm{~g})$ was applied to reversed phase medium-pressure liquid chromatography and developed with an $\mathrm{MeOH}$-water stepwise system $(0$, $10,20,30,40,50,60,70,80,90$ and $100 \%$ ) to yield an active fraction $(97.0 \mathrm{mg})$ in $80 \% \mathrm{MeOH}$ eluate. The active fraction was chromatographed on normal phase medium-pressure liquid chromatography with $\mathrm{CHCl}_{3}-\mathrm{MeOH}(3: 2)$. The active eluates were purified by the preparative reversed phase HPLC, developed with $75 \% \mathrm{MeOH}-\mathrm{H}_{2} \mathrm{O}$, including $0.1 \%$ formic acid (flow rate: $10 \mathrm{ml} \mathrm{min}^{-1}$ ) to yield 1 (13.1 mg, Rt $16 \mathrm{~min})$, and 2 (6.1 mg, Rt $22 \mathrm{~min})$.

\section{Structure elucidation}

The physicochemical properties of $\mathbf{1}$ and $\mathbf{2}$ were summarized in Table 1. Compound $\mathbf{1}$ was obtained as a colorless amorphous powder, and its molecular formula was established as $\mathrm{C}_{26} \mathrm{H}_{48} \mathrm{NO}_{9} \mathrm{P}$ by HR-ESIMS data $\left[m / z 550.3142(\mathrm{M}+\mathrm{H})^{+}\right]$, and was also supported by ${ }^{13} \mathrm{C}$, ${ }^{1} \mathrm{H}$ and ${ }^{31} \mathrm{P}$ NMR data. IR spectrum showed absorbance for hydroxyl $\left(v_{\max } 3400 \mathrm{~cm}^{-1}\right)$ and ester carbonyl $\left(v_{\max } 1730 \mathrm{~cm}^{-1}\right)$ groups. The direct connectivity between each proton and carbon was established by the HSQC (heteronuclear single quantum coherence) spectrum, and the ${ }^{13} \mathrm{C}$ and ${ }^{1} \mathrm{H}$ NMR spectral data for $\mathbf{1}$ are shown in Table 2. Three partial structures were established by double-quantum filtered (DQF)-COSY and heteronuclear multiple bond correlation (HMBC) spectra as follows:

A spin coupling between oxymethylene protons of $25-\mathrm{H}\left(\delta_{\mathrm{H}} 3.86\right)$ and aminomethylene protons of $26-\mathrm{H}\left(\delta_{\mathrm{H}} 2.94\right)$ indicated the presence of ethanolamine moiety (Figure 1 ). The sequence from a terminal methyl proton $24-\mathrm{H}\left(\delta_{\mathrm{H}} 1.13\right)$ to methylene protons $16-\mathrm{H}$ $\left(\delta_{\mathrm{H}} 1.308\right)$ through an oxymethine proton $23-\mathrm{H}\left(\delta_{\mathrm{H}} 4.80\right)$, methylene protons $22-\mathrm{H}\left(\delta_{\mathrm{H}} 1.50,1.43\right), 21-\mathrm{H}\left(\delta_{\mathrm{H}} 1.310\right), 20-\mathrm{H}\left(\delta_{\mathrm{H}} 2.01 \sim 1.88\right)$, two olefinic protons $19-\mathrm{H}\left(\delta_{\mathrm{H}} 5.36\right), 18-\mathrm{H}\left(\delta_{\mathrm{H}} 5.30\right)$ and methylene protons $17-\mathrm{H}\left(\delta_{\mathrm{H}} 2.01 \sim 1.88\right)$ was observed in DQF-COSY spectrum. The ${ }^{1} \mathrm{H}-{ }^{13} \mathrm{C}$ long-range couplings from methylene protons $16-\mathrm{H}, 18-\mathrm{H}$ and $19-\mathrm{H}$ to an allylic carbon $\mathrm{C}-17\left(\delta_{\mathrm{C}} 31.6\right)$, and from $18-\mathrm{H}, 19-\mathrm{H}$, $22-\mathrm{H}$ and $23-\mathrm{H}$ to an allylic carbon $\mathrm{C}-20\left(\delta_{\mathrm{C}} 31.7\right)$ also supported the connectivity of allylic carbons. Thus, a 2 -oxy-6-nonene moiety was established as a partial structure of $\mathbf{1}$ as shown in Figure 1. The stereochemistry at C-18 was deduced to possess an $E$ configuration from its coupling constant $\left(J_{18,19}=15.0 \mathrm{~Hz}\right)$. Another sequence from methylene protons $2-\mathrm{H}\left(\delta_{\mathrm{H}} 2.28,2.22\right)$ to methylene protons $10-\mathrm{H}$ $\left(\delta_{\mathrm{H}} 1.40,1.23\right)$ through methylene protons $3-\mathrm{H}\left(\delta_{\mathrm{H}} 1.64\right), 4-\mathrm{H}\left(\delta_{\mathrm{H}}\right.$ $1.56)$, an oxymethine proton $5-\mathrm{H}\left(\delta_{\mathrm{H}} 3.75\right)$, two epoxy protons $6-\mathrm{H}$ $\left(\delta_{\mathrm{H}} 2.89, \delta_{\mathrm{C}} 58.4\right), 7-\mathrm{H}\left(\delta_{\mathrm{H}} 2.85, \delta_{\mathrm{C}} 57.7\right)$, two oxymethine protons 8$\mathrm{H}\left(\delta_{\mathrm{H}} 2.91, \delta_{\mathrm{C}} 75.3\right)$ and $9-\mathrm{H}\left(\delta_{\mathrm{H}} 3.36, \delta_{\mathrm{C}} 72.1\right)$ established a $2,3,6-$ trioxy-4,5-epoxynonane moiety. The existence of an epoxy group at the position of C- 6 and C-7 was determined by their characteristic ${ }^{13} \mathrm{C}$ shifts, and its stereochemistry was determined as trans by its coupling 
Table $2{ }^{13} \mathrm{C}(125 \mathrm{MHz})$ and ${ }^{1} \mathrm{H}(500 \mathrm{MHz})$ NMR spectra of 1 and 2

\begin{tabular}{|c|c|c|c|c|}
\hline \multirow[b]{2}{*}{ Position } & \multicolumn{2}{|r|}{1} & \multicolumn{2}{|r|}{2} \\
\hline & $\delta_{C}$ & $\delta_{H}($ multiplicity, $\mathrm{J}$ in $\mathrm{Hz}$ ) & $\delta_{C}$ & $\delta_{H}($ multiplicity, $J$ in $\mathrm{Hz})$ \\
\hline 2 & 33.9 & $2.28(\mathrm{dt}, 16.1,7.1) ; 2.22(\mathrm{dt}, 16.1,7.1)$ & 34.0 & $2.26(t, 7.0)$ \\
\hline 3 & 20.0 & 1.64 (pentet, 7.1 ) & 20.1 & $1.60(\mathrm{~m})$ \\
\hline 4 & 32.2 & $1.56(\mathrm{~m})$ & 32.2 & $1.55(\mathrm{~m})$ \\
\hline 7 & 57.7 & $2.85(\mathrm{dd}, 7.1,1.5)$ & 53.6 & $2.88(b r t, 5.8)$ \\
\hline 8 & 75.3 & $2.91(\mathrm{~m})$ & 39.6 & $1.74(\mathrm{dt}, 13.4,5.4) ; 1.30(\mathrm{~m})$ \\
\hline 9 & 72.1 & $3.36(\mathrm{~m})$ & 67.7 & $3.59(p, 5.1)$ \\
\hline 10 & 25.6 & $1.40(\mathrm{~m}) ; 1.23(\mathrm{~m})$ & 28.22 & $1.310(\mathrm{~m})$ \\
\hline \multirow[t]{2}{*}{$11 \sim 15$} & 31.8 & $1.44(\mathrm{~m}) ; 1.233(\mathrm{~m})$ & 36.4 & $1.36(\mathrm{~m}) ; 1.305(\mathrm{~m})$ \\
\hline & 28.8 & $1.23(\mathrm{~m})$ & 28.5 & $1.235(\mathrm{~m})$ \\
\hline 17 & 31.6 & $2.01-1.88(\mathrm{~m})$ & 31.5 & $2.01-1.87(\mathrm{~m})$ \\
\hline 18 & 130.6 & $5.30(\mathrm{dd}, 15.0,5.5)$ & 130.6 & $5.29(\mathrm{dd}, 15.0,5.5)$ \\
\hline 19 & 130.4 & $5.36(d d, 15.0,5.5)$ & 130.3 & $5.34(\mathrm{dd}, 15.0,5.5)$ \\
\hline 20 & 31.7 & $2.01-1.88(\mathrm{~m})$ & 31.7 & $2.01-1.87(\mathrm{~m})$ \\
\hline 21 & 24.9 & $1.310(\mathrm{~m})$ & 24.9 & $1.315(\mathrm{~m})$ \\
\hline 22 & 34.7 & $1.50(\mathrm{~m}) ; 1.43(\mathrm{~m})$ & 34.7 & $1.51(\mathrm{~m}) ; 1.43(\mathrm{~m})$ \\
\hline 23 & 70.2 & $4.80(\operatorname{sex}, 6.3)$ & 70.2 & $4.80(\operatorname{sex}, 6.1)$ \\
\hline 24 & 20.1 & $1.13(\mathrm{~d}, 6.1)$ & 20.1 & $1.13(\mathrm{~d}, 6.4)$ \\
\hline 25 & 61.4 & $3.86(\mathrm{br} \mathrm{s})$ & 61.5 & $3.84(\mathrm{~m})$ \\
\hline 26 & 41.1 & $2.94(\mathrm{br} \mathrm{s})$ & 41.2 & 2.92 (br s) \\
\hline
\end{tabular}

constant $\left(J_{6,7}=1.5 \mathrm{~Hz}\right)$. The ${ }^{1} \mathrm{H}_{-}{ }^{13} \mathrm{C}$ long-rang couplings from $23-\mathrm{H}$, $2-\mathrm{H}, 3-\mathrm{H}$ to an ester carbonyl carbon $\mathrm{C}-1\left(\delta_{\mathrm{C}} 172.6\right)$, together with ${ }^{1} \mathrm{H}-{ }^{1} \mathrm{H}$ correlations from both of $10-\mathrm{H}$ and $16-\mathrm{H}$ to the remaining methylene chain $\left(\mathrm{C}_{5} \mathrm{H}_{10}\right.$ unit for $11-\mathrm{H}$ to $\left.15-\mathrm{H}, \delta_{\mathrm{H}} 1.44-1.21\right)$, established a 24-membered macrolide skeleton (Figure 1). A peak of $\delta_{\mathrm{P}}$ at $-0.448 \mathrm{ppm}$ in ${ }^{31} \mathrm{P}$ NMR spectra indicated the presence of a phosphoric acid or a phosphoryl group. The oxymethylene carbon C-5 $\left(\delta_{\mathrm{C}} 74.4\right)$ and the oxymethine carbon C-25 $\left(\delta_{\mathrm{c}} 61.4\right)$ were observed as doublet signals $\left({ }^{2} J_{\mathrm{C}-5, \mathrm{P}}=6.5 \mathrm{~Hz},{ }^{2} J_{\mathrm{C}-25, \mathrm{P}}=4.8 \mathrm{~Hz}\right.$, respectively), whereas their neighboring carbons were observed as doublet or broad singlet signals $\left(\mathrm{C}-4: \delta_{\mathrm{C}} 32.2\right.$, br d, ${ }^{3} \mathrm{~J}_{\mathrm{C}-4, \mathrm{P}}=3.5 \mathrm{~Hz}$; C-6: d, ${ }^{3} J_{\mathrm{C}-6, \mathrm{P}}=4.8 \mathrm{~Hz} ; \mathrm{C}-26: \delta_{\mathrm{C}} 41.1$, br s), suggesting C-5 and C-25 to be connected through a phosphodiester bond. Thus, the structure of 1 was determined as shown in Figure 2.

Compound 2 was obtained as a colorless amorphous powder and has a molecular formula, $\mathrm{C}_{26} \mathrm{H}_{48} \mathrm{NO}_{8} \mathrm{P}$, based on HR-ESI-MS data $\left[\mathrm{m} / \mathrm{z} 534.3166(\mathrm{M}+\mathrm{H})^{+}\right]$. IR spectrum indicated the presence of hydroxyl $\left(v_{\max } 3400 \mathrm{~cm}^{-1}\right)$ and an ester carbonyl $\left(v_{\max } 1726 \mathrm{~cm}^{-1}\right)$ groups. The NMR spectral data (Table 2) were similar to those of $\mathbf{1}$, and HR-ESI-MS data showed the difference of 16 mass units as an oxygen atom compared with that of $\mathbf{1}$. A peak of a phosphoric acid or a phosphoryl group at $\delta_{\mathrm{P}}-0.436$ p.p.m. in the ${ }^{31} \mathrm{P}$ NMR spectra showed as the same as that of $\mathbf{1}$. A spin coupling between oxymethylene protons of $25-\mathrm{H}\left(\delta_{\mathrm{H}} 3.84\right)$ and aminomethylene protons of $26-\mathrm{H}$ $\left(\delta_{\mathrm{H}} 2.92\right)$, the sequences from methylene protons $2-\mathrm{H}\left(\delta_{\mathrm{H}} 2.26\right)$ to methylene protons $10-\mathrm{H}\left(\delta_{\mathrm{H}} 1.310\right)$, and from a methyl proton $24-\mathrm{H}$ $\left(\delta_{\mathrm{H}} 1.13\right)$ to methylene protons $16-\mathrm{H}\left(\delta_{\mathrm{H}} 1.310\right)$ were observed in an ${ }^{1} \mathrm{H}-{ }^{1} \mathrm{H}$ DQF-COSY experiment in the same manner as those of $\mathbf{1}$
(Figure 1), whereas remarkable difference was observed at a methylene carbon $\mathrm{C}-8\left(\delta_{\mathrm{C}} 39.6 ; \delta_{\mathrm{H}} 1.74,1.30\right)$, which was high-field shifted compared with the hydroxyl methine carbon C-8 of $1\left(\delta_{\mathrm{C}} 75.3\right.$; $\left.\delta_{\mathrm{H}} 2.91\right)$. The geochemistry of the olefin at C-18 $\left(\delta_{\mathrm{C}} 130.6\right)$ was determined as trans from its coupling constant $\left(J_{18,19}=15.0 \mathrm{~Hz}\right)$, similar to that of $\mathbf{1}$. On the other hand, the stereochemistry of the oxacyclopropane ring between C-6 $\left(\delta_{\mathrm{C}} 60.5\right)$ and C-7 $\left(\delta_{\mathrm{C}} 53.6\right)$ was determined as $c i$ from its coupling constant $\left(J_{6,7}=5.8 \mathrm{~Hz}\right)$. Therefore, 2 was established to be an 8-deoxy derivative of 1 (Figure 2).

We, herein, isolated two 24-membered macrolide compounds with phosphate ester $\mathbf{1}$ and $\mathbf{2}$ from the culture broth of Metarhizium sp. fE61. Metarhizium sp. is known to be entomopathogenic fungus and produces several secondary metabolites, such as nonribosomal peptides (destruxins, ${ }^{6}$ serinocyclins ${ }^{7}$ ), nor-triterpenoids (helvolic acids, ${ }^{8}$ viridoxins ${ }^{9}$ ) and polyene compounds (aurovertins, ${ }^{10}$ NG-391, NG-393 ${ }^{11}$ ). 1 and 2 are the first report that Metarhizium sp. produces macrolide compounds. The similar carbon framework to $\mathbf{1}$ and $\mathbf{2}$ is only reported as eushearilide, isolated from Eupenicillium shearii ${ }^{12}$ as a fungal metabolite. The structures of 1 and 2 , however, differ from that of eushearilide in the presence of highly oxygenated functional groups (epoxy and hydroxyl), the substituted position of the phosphate ester and the olefinic groups.

\section{Biological activity}

We evaluated the cell morphological change of diploid wild-type S. cerevisiae by $\mathbf{1}$ and $\mathbf{2}$ using visual observation with phase contrast microscopy. The cells treated with $\mathbf{1}$ and $\mathbf{2}$ showed striking elongated morphology at the concentrations of 3.1 and $13 \mu \mathrm{M}$, respectively 


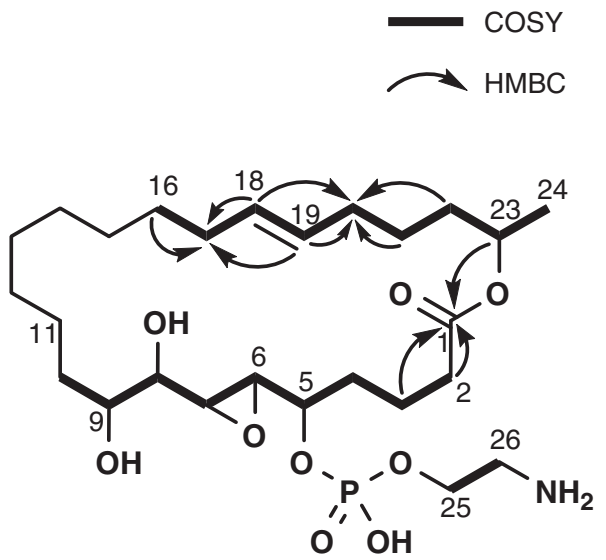

1

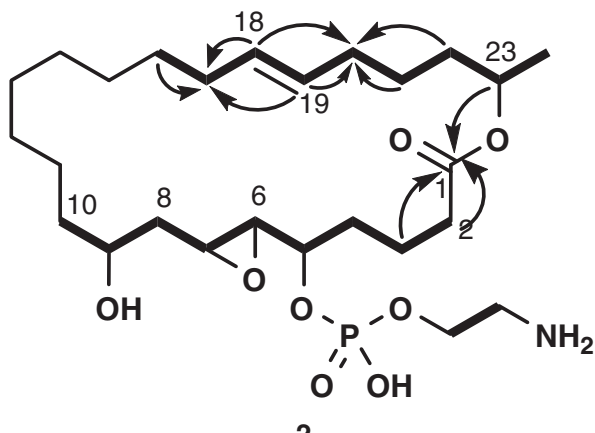

2

Figure 1 Key correlations in 2D NMR for 1 and $2\left({ }^{1} H_{-}{ }^{1} \mathrm{H}\right.$ DQF-COSY and $\mathrm{HMBC})$.

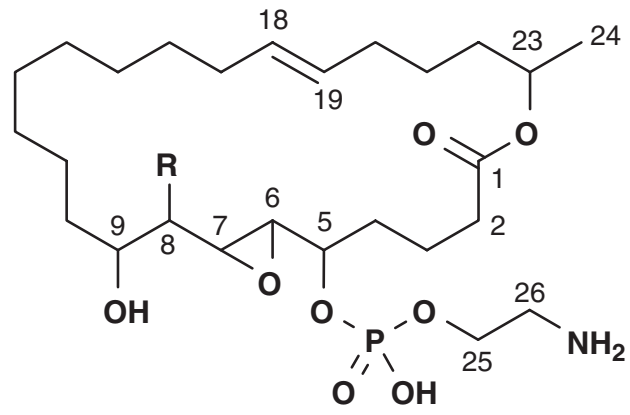

JBIR-19 (1) : $\mathrm{R}=\mathrm{OH}$

JBIR-20 (2) : R = H

Figure 2 Structures of 1 and 2

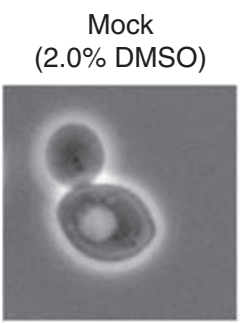

JBIR-19

$(3.1 \mu \mathrm{M})$

JBIR-20

$(13 \mu \mathrm{M})$
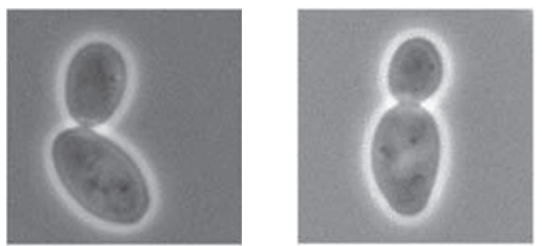

Figure 3 Phase contrast images of diploid wild-type $\mathbf{S}$. cerevisiae grown in the presence or absence of $\mathbf{1}$ and $\mathbf{2}$.

(Figure 3). To the contrary, 1 exhibited weak antimicrobial activity at MICs of $200 \mu \mathrm{M}$, whereas 2 did not show antimicrobial activity at the concentration of $200 \mu \mathrm{M}$. As the cyclin-dependent kinases and/or mitotic cyclins mutants of $S$. cerevisiae indicate striking elongated morphology, the cell morphology is closely related to $M$ phase progression in the cell cycle. ${ }^{13}$ Thus, these results suggest that $\mathbf{1}$ and 2 inhibit M phase progression and induce striking elongated morphology. Studies on detailed biological activity of $\mathbf{1}$ are now underway.

\section{ACKNOWLEDGEMENTS}

This study was supported by a grant from the New Energy and Industrial Technology Department Organization (NEDO) of Japan.

1 Ohya, Y. et al. High-dimensional and large-scale phenotyping of yeast mutants. Proc. Natl. Acad. Sci. USA 102, 19015-19020 (2005).

2 Hayakawa, M. \& Nonomura, H. A new method for the intensive isolation of actinomycetes from soil. Actinomycetol 3, 95-104 (1989).

3 Brachmann, C. B. et al. Designer deletion strains derived from Saccharomyces cerevisiae S288C: a useful set of strains and plasmids for PCR-mediated gene disruption and other applications. Yeast 14, 115-132 (1998).

4 Mavridou, A., Cannone, J. \& Typas, M. A. Identification of group-I introns at three different positions within the 28S rDNA gene of the entomopathogenic fungus Metarhizium anisopliae var anisopliae. Fungal. Genet. Biol. 31, 79-90 (2000).

5 Domsch, K. H., Gams, W. \& Anderson, T. Compendium of soil fungi, 2nd edn. (IHW-Verlag \& Verlagsbuchhandlung, Eching, 2007).

6 Liu, B. L., Chen, J. W. \& Tzeng, Y. M. Production of cyclodepsipeptides destruxin A and B from Metarhizium anisopliae. Biotechnol. Prog. 16, 993-999 (2000).

7 Krasnoff, S. B. et al. Serinocyclins A and B, cyclic heptapeptides from Metarhizium anisopliae. J. Nat. Prod. 70, 1919-1924 (2007).

8 Lee, S. Y., Kinoshita, H., Ihara, F., Igarashi, Y. \& Nihira, T. Identification of novel derivative of helvolic acid from Metarhizium anisopliae grown in medium with insect component. J. Biosci. Bioeng. 105, 476-480 (2008).

9 Gupta, S. et al. Viridoxins A and B: Novel toxins from the fungus Metarhizium flavoviride. J. Org. Chem. 58, 1062-1067 (1993).

10 Azumi, M. et al. Aureovertins F-H from the entomopathogenic fungus Metarhizium anisopliae. J. Nat. Prod. 71, 278-280 (2008).

11 Krasnoff, S. B. et al. Production of mutagenic metabolites by Metarhizium anisopliae. J. Agric. Food Chem. 54, 7083-7088 (2006).

12 Hosoe, T. et al. A new antifungal macrolide, eushearilide, isolated from Eupenicillium shearii. J. Antibiot. 59, 597-600 (2006).

13 Ahn, S. H. et al. Enhanced cell polarity in mutants of the budding yeast cyclindependent kinase Cdc28p. Mol. Biol. Cell 12, 3589-3600 (2001). 